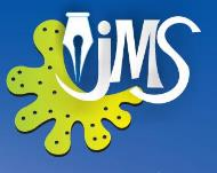

\title{
Impact of Compliance with Principles on Board of Directors and Corporate Performance: Empirical Evidence from Sri Lankan Listed Companies
}

\author{
Dissanayake D.H.S.W. ${ }^{1^{*}}$, Dissabandara D.B.P.H. ${ }^{2}$ and Ajward A.R. ${ }^{2}$ \\ ${ }^{1}$ Wayamba University of Sri Lanka \\ ${ }^{2}$ University of Sri Jayawardenapura
}

\begin{abstract}
Board of directors in corporate governance is conceptualized as the perceived ability of a firm to constrain and direct corporate power so that it efficiently creates economic value and equitably distributes economic wealth. Accordingly, this study examines the relationship between the level of compliance with the principles on corporate governance related to the board of directors and corporate performance of listed firms in Sri Lanka using secondary data related to 133 listed companies from 2009 to 2016. This study constructed Board Index related to dimensions (principles): Chairmanship, Nomination Committee, Audit Committee, Remuneration Committee, and Re-election of directors, Company Secretary, Role of the Board, Board Meetings and Board Independence. This study employs panel regression model to examine the relationship between the Board Index (BI) and their relationship with corporate performance and performed with Hausman test for random and fixed effects. The findings indicated that the compliance with these principles are positively related to the financial performance and negatively related with market performance. Thus, this study provides empirical support for the agency perspective in the context of compliance requirements of board of directors leading to higher corporate performance. Insights of this research are offered to listed firms by the compliance of corporate governance principles have the potential to improve company performance.
\end{abstract}

KEYWORDS: Agency Perspective, Audit Committee, Corporate Governance, Nomination committee, Remuneration Committee 


\section{INTRODUCTION}

Board of directors performs an imperative role in the governance structure of large organizations (Fama \& Jenson 1983). The two main functions of the board are decision management and decision control according to the Agency theory. (Fama \& Jenson 1983). The board of directors' acts as the formal association between the shareholders of the firm and the managers delegated with running the organization (Monks \& Minow 1996). Hence, Fama and Jenson (1983) quoted board as "the apex of the firm's decision control system", which Dalton et al. (1996) highlight that the board plays a key role in monitoring and controlling managers. Tricker (2015) elucidated four main roles of the board including discharging accountability, strategy formulation, supervising executive activities and policy making.

The corporate governance codes could be considered as implicit portrayals of the insights from the agency theory, which has encouraged firms to strengthen the monitoring capacity of their boards. Cadbury, OECD (1999) defined corporate governance as "the system by which business corporations are directed and controlled" and the Financial Reporting Council (2016, p.1) suggests "Boards of directors are responsible for the governance of their companies". Accordingly, Cadbury Code obliquely portrayal on the discernments from Agency Theory has stimulated firms to fortify monitoring capacity of boards. This is to be accomplished by establishing CEO-Chair duality and by encouraging independence of the board and its key monitoring committees among other recommendations (Cadbury 1992).
Hence, theoretically, greater compliance with board-related corporate governance requirements should be accompanied with reduced agency problems, and hence greater operating performance and firm value (Adams, Hermalin, \& Weisbach 2010, Renders, Gaeremynck, \& Sercu 2010). It is noted that studies examining the governance-performance link based on individual governance mechanisms have found mixed results (Vafeas \& Theodorou 1998, Weir et al. 2002, Agrawal \& Knoeber 1996, Bhagat \& Black 1999).

There have been numerous studies on Corporate Governance related to role of board of directors but Carvor (2010) argues that universally applicability of the findings and conclusions of those studies is debatable owing to various contextual causes concerning to research settings political stability, cultural backgrounds and institutional constraints. Specifically, developing countries issues related to board of directors is different from developed economies due to different contextual settings. Van et al. (2012) found that no direct relationship between board of directors and performance in Asian firms. Further they found that board attributes that are held to typify good governance practices are not exhibited in Asian firms.

Further, in the Sri Lankan context, corporate governance principles had been increasingly pronounced in the recent past and the revised and expanded code of best practice on corporate governance was issued in 2017. Despite significant efforts to establish a sound regulatory framework for corporate governance in Sri Lanka, studies on corporate governance practices at the firm level and their effects on firm performance is not sufficient with recent data. Accordingly, based on the above discussion, the main research objective in 
this study is to examine the relationship between the level of compliance with corporate governance principles related to board of directors and corporate performance of the listed companies in Sri Lanka.

This paper is organized as follows. The next section reviews relevant literature and formulate hypothesis; section 3 describes the data and research method deployed in addressing the aforementioned research issue. Section 4 discusses the analysis of the study, and finally the paper ends with discussion and conclusion.

\section{BACKGROUND/LITERATURE SURVEY}

This section examines the extant literature related to the board of directors and performance and the relationship between different board dimensions and performance and the hypothesis developed in accordance with the empirical literature.

\subsection{Board Independence and Firm Performance}

Board independence is represented by nonexecutive directors in the board. The primary responsibility for board oversight reposes with the independent non-executive directors (Fama \& Jenson 1983). There are two conflicting theoretical groundworks used to explain this problem and its subsequent impact on firm performance, i.e., the agency theory (Fama 1980 Fama \& Jensen 1983, Jensen \& Meckling 1976) and the stewardship theory (Davis, Schoorman \& Donaldson 1997, Donaldson 1990a, 1990b, Donaldson \& Davis 1991). Agency theorists argue that there is an inescapable conflict between parties, such as principals and agents. The independence of directors may enable boards to perform their oversight functions more effectively because such boards are considered to be independent
(Finkelstein \& Mooney, 2003). Consequently, agency theory proposes a positive relationship between board independence and firm performance (Boyd, 1995). On the other hand, the stewardship theory holds an optimistic view of human (managerial) behaviour, and dispute that agents are not essentially motivated by individual goals and that rather they are intrinsically reliable and not predisposed to embezzle corporate resources and are motivated to work in the interest of their principals and other stakeholders (Davis et al. 1997, Donaldson 1990a, 1990b, Donaldson \& Davis 1991). Furthermore, this theory recommends that the optimal stewardship role can only be exercised when the board has the ultimate power and authority. Therefore, this theory suggests an inverse relationship between board independence and performance.

As in the case of above theoretical explanations, the empirical evidence related to the relationship between Board Independence and performance is also mixed. The results of the board independence and performance is summarized in the Table 1 below. 
Table 1: Literature related to the board independence

\begin{tabular}{|c|c|c|c|}
\hline Author & Article & Country & Relationship \\
\hline $\begin{array}{l}\text { Pearce \& Zahra, } \\
(1991)\end{array}$ & $\begin{array}{l}\text { The relative power of CEOs and boards } \\
\text { of directors: Associations with corporate } \\
\text { performance }\end{array}$ & USA & Positive \\
\hline $\begin{array}{l}\text { Ezzamel \& Watson, } \\
\text { (1993) }\end{array}$ & $\begin{array}{l}\text { Organizational Form, Ownership } \\
\text { Structure and Corporate Performance: A } \\
\text { Contextual Empirical Analysis of UK } \\
\text { Companies }\end{array}$ & UK & Positive \\
\hline $\begin{array}{l}\text { Hossain, Prevost \& } \\
\text { Roa, (2001) }\end{array}$ & $\begin{array}{l}\text { Corporate Governance in New Zealand: } \\
\text { The effect of the } 1993 \text { Companies Act on } \\
\text { the relation between board composition } \\
\text { and firm performance }\end{array}$ & $\begin{array}{l}\text { New } \\
\text { Zealand }\end{array}$ & Positive \\
\hline $\begin{array}{l}\text { Choi, Park \& Yoo, } \\
\text { (2007) }\end{array}$ & $\begin{array}{l}\text { The value of outside directors: Evidence } \\
\text { from corporate governance reform in } \\
\text { Korea }\end{array}$ & Korea & Positive \\
\hline $\begin{array}{l}\text { Grace, Ireland \& } \\
\text { Dunstan(1995) }\end{array}$ & $\begin{array}{l}\text { Board composition, non-executive } \\
\text { directors' characteristics and corporate } \\
\text { financial performance }\end{array}$ & Australia & Negative \\
\hline $\begin{array}{ll}\text { Baysinger } & \& \\
\text { Butler(1985) } & \end{array}$ & $\begin{array}{l}\text { Corporate governance and the board of } \\
\text { directors: Performance effects of changes } \\
\text { in board composition }\end{array}$ & USA & Negative \\
\hline $\begin{array}{l}\text { Bhagat \& Black, } \\
\text { (2002) }\end{array}$ & $\begin{array}{l}\begin{array}{l}\text { The non-correlation } \\
\text { independence and lotween }\end{array} \\
\text { performance }\end{array}$ & USA & Negative \\
\hline $\begin{array}{l}\text { Chaganti, Mahajan } \\
\text { \& Sharma(1985); }\end{array}$ & $\begin{array}{l}\text { Corporate board size, composition and } \\
\text { corporate failures in retailing industry }\end{array}$ & USA & Negative \\
\hline $\begin{array}{l}\text { Hermalin } \& \\
\text { Weisbach, (2010) }\end{array}$ & $\begin{array}{l}\text { The Role of Boards of Directors in } \\
\text { Corporate Governance: A Conceptual } \\
\text { Framework and Survey. }\end{array}$ & USA & Negative \\
\hline $\begin{array}{ll}\text { Rechner } & \& \\
\text { Dalton(1986) } & \\
\end{array}$ & $\begin{array}{l}\text { Board composition and shareholder } \\
\text { wealth: An empirical assessment }\end{array}$ & USA & Negative \\
\hline Yermack(1996) & $\begin{array}{l}\text { Higher market valuation of companies } \\
\text { with a small board of directors }\end{array}$ & USA & Negative \\
\hline $\begin{array}{l}\text { Rashid, De Zoysa, } \\
\text { Lodh \& Rudkin, } \\
(2010)\end{array}$ & 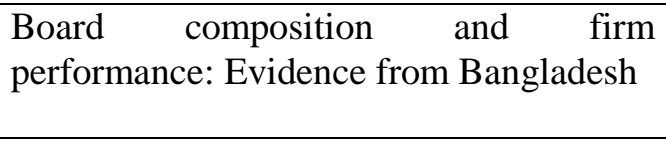 & Bangladesh & Negative \\
\hline
\end{tabular}

Source: Constructed by the Authors based on the literature

Accordingly, based on the above theoretical and empirical evidence the first hypothesis of this study could be established and stated as follows:

$\mathrm{H}_{1}$ : There is a positive relationship between board independence and performance

\subsection{Board Chairman and Performance}

The empirical evidence related to the principles related to the board chairmanship and performance is mainly based on CEO duality. This means one person holds both chairman and CEO positions in a firm 
(Boyd 1995). According to the Agency theory, separating two positions are desirable in order to reduce the potential conflicts of interest, but Stewardship theory suggests that integrating the two positions advocates that unequivocal authority and unique leadership power over the authorities.
As in the case of independence and firm performance, the empirical evidence related to the relationship between board independence and performance is also mixed. The results of the board independence and performance are summarized in the Table 2 below.

Table 2: Literature related the Chairman and Performance

\begin{tabular}{|l|l|l|l|}
\hline Author & Article & Country & Relationship \\
\hline $\begin{array}{l}\text { Daily \& Dalton } \\
(1992)\end{array}$ & $\begin{array}{l}\text { The relationship between governance } \\
\text { structure and corporate performance in } \\
\text { entrepreneurial firm }\end{array}$ & USA & No relationship \\
\hline $\begin{array}{l}\text { Brickley et al. } \\
(1997)\end{array}$ & $\begin{array}{l}\text { Leadership structure: Separating the } \\
\text { CEO and chairman of the board }\end{array}$ & USA & No relationship \\
\hline $\begin{array}{l}\text { Sanda et al. } \\
(2003))\end{array}$ & $\begin{array}{l}\text { Corporate governance mechanisms and } \\
\text { firm financial performance in Nigeria }\end{array}$ & Nigeria & Positive \\
\hline $\begin{array}{l}\text { Donaldson and } \\
\text { David (1995) }\end{array}$ & $\begin{array}{l}\text { Boards and company performance - } \\
\text { Research challenges the conventional } \\
\text { wisdom }\end{array}$ & USA & Negative \\
\hline Azeez (2015) & $\begin{array}{l}\text { Corporate governance and firm } \\
\text { performance: evidence from Sri Lanka }\end{array}$ & Sri Lanka & Negative \\
\hline
\end{tabular}

Source: Constructed by the authors based on extant literature

Accordingly, based on the above discussion, the second hypothesis of this study could be established and indicated as follows:

$\mathrm{H}_{2}$ : There is a positive relationship between corporate governance principles related to board chairmanship and firm performance

\section{Board Committees and Performance}

The recommendations of Cadbury (1992) suggest that the board's monitoring role can further be improved by establishing oversight board committees which enable the directors' duties to be meticulously.
The empirical evidence related to the relationship between board committees and performance is also observed to be mixed. The results of the board committees and performance are summarized in the Table 3 below. 
Table 3: Literature related to Board Committees and Performance

\begin{tabular}{|l|l|l|l|}
\hline Author article & Country & Relationship \\
\hline $\begin{array}{l}\text { Dionne and } \\
\text { Triki (2005) }\end{array}$ & $\begin{array}{l}\text { Risk management and corporate governance: } \\
\text { The importance of independence and financial } \\
\text { knowledge for the board and the audit } \\
\text { committee }\end{array}$ & Positive \\
\hline $\begin{array}{l}\text { Hilman et al. } \\
\text { (2008) }\end{array}$ & $\begin{array}{l}\text { Directors' multiple role identities, identification } \\
\text { and board monitoring and resource provision }\end{array}$ & UK & Positive \\
\hline $\begin{array}{l}\text { Adjoud et.al. } \\
(2007)\end{array}$ & $\begin{array}{l}\text { The effect of board's quality on performance: A Canada } \\
\text { study of Canadian firms. }\end{array}$ & Positive \\
\hline Klein (1998) and & $\begin{array}{l}\text { Firm performance and board committee } \\
\text { structure }\end{array}$ & $\begin{array}{l}\text { The relationship between board structure and } \\
\text { firm performance in the UK }\end{array}$ & $\begin{array}{l}\text { No } \\
\text { relationship }\end{array}$ \\
\hline $\begin{array}{l}\text { Vafeas } \\
\text { Theodorou } \\
\text { (1998) }\end{array}$ & $\begin{array}{l}\text { Does the composition and practice of boards of } \\
\text { directors bear any relationship to the } \\
\text { performance of their companies }\end{array}$ & relationship \\
Herbert (2004) & $\begin{array}{l}\text { Size really matters: Further evidence on the } \\
\text { negative relationship between board size and } \\
\text { firm value. }\end{array}$ & Singapore \\
\hline $\begin{array}{l}\text { Mak } \\
\text { Kusnadi (2005) }\end{array}$ & $\begin{array}{l}\text { No } \\
\text { relationship }\end{array}$ \\
\hline
\end{tabular}

Source: Constructed by the authors based on extant literature

Based on the above discussion, the third hypothesis of this study could be indicated as follows:

$\mathrm{H}_{3}$ : There is a positive relationship between the presence of independent committees of the board and performance.

\subsection{Board Meeting Frequency and Performance}

According to the Resource Dependency theory, active board involvement is important to enhance performance (Hillmanet.al 2009). Jackling and Johl (2009) suggest that board meeting frequency is a main parameter to measure board activity. The board meeting is a medium set up for deliberations on key issues and matters amongst board members in order to make certain important decisions for the progress and growth of any organization. Board of directors hold more meetings results in increasing their capacity to advise, control and ensure discipline in an organization, so as to improve corporate firm performance (Ntim \& Osei 2011). Thus, this relationship is also supported by the Agency theory. Francis et al. (2012b) and Ntim and Osei (2011) suggest that when the board meets more frequently, this will increase their ability to effectively monitor, advice, scrutinize and create an atmosphere of discipline. Based on these arguments, the fourth hypothesis could be established and depicted as follows:

$\mathrm{H}_{4}$ : There is a positive relationship between the board meeting frequency and firm performance. 


\subsection{Overall Board Index and Performance}

Observation of extant literature indicates that there is a limited number of extant research that use the overall board related principles of corporate governance (i.e., in terms of a board index) in the world. Sahakuat and Grzegroz (2018) has found strong positive relationship between board index and performance. In their study, 13 dimensions of board governance principles are considered including principles related to CEO-Chair duality, Board Independence, Nomination Committee, Remuneration Committee and Audit Committee.

In the Sri Lankan context, Dissabandara (2010) has constructed Board Index using 14 dimensions including strategic direction, legal and ethical compliance, board meetings, board structure, external relations and board-staff roles in addition to sahakuat A. and Grzegroz T.(2018). Dissabandara(2010)study only measure the board index and the average compliance level of board index was 56 .

Based on the above observations, this study hypothesizes that:

$\mathrm{H}_{5}$ : There is a positive relationship between Board Governance Index and Performance

\section{RESEARCH METHODOLOGY / MATERIALS AND METHODS}

This study examines the relationship between corporate governance principles related to the board and firm performance of listed companies in Sri Lanka. Thus, it is based on a positivist paradigm and uses a deductive reasoning in establishing the causes and effects of a thus social phenomenon (Hussey \& Hussey 1997). The reasoning is deductive because the hypotheses are derived first, and then the related data will be collected later to confirm or negate these established hypotheses. Bryman and Bell (2007) indicate that the deductive approach is related to quantitative research that follows objectivism, ontological realism and epistemological positivism. Gill and Johnson (2002) argued that the development of a conceptual and theoretical structure prior to its testing through empirical observation is needed in a deductive research method. As a result, quantitative data will be used as the evidence required for testing the hypotheses in this study.

The population for this study consists of public listed companies incorporated under the Companies Act No. 7 of 2007 and listed under the Colombo Stock Exchange (www.cse.lk). The Colombo Stock Exchange comprises 295 companies representing 20 business sectors as at $31^{\text {st }}$ December 2016. This study would consider only the companies listed before 31/12/2009 and continued till December 2016.

This study used a stratified sampling method to select the sample of companies, whereby the population was divided into non-overlapping sub-populations based on the business sectors of the Colombo Stock Exchange. This sampling method is used to obtain a representative sample across the sectors listed on CSE. CSE classified listed companies under 20 sectors. The sample of 130 listed companies are selected based on the sector-wise highest market capitalization on thirty first December 2016. First, 150 companies were selected based on the highest market capitalization. Next the companies registered after 2009 has excluded from the sample. Second, in order to select a representative sample based on individual sectors, a minimum of five companies were identified from each sector which had higher market capitalization in the respective sectors. Table 4 depict the sample selection and representation of the total population. 
Table 4: Final Sample

\begin{tabular}{llll}
\hline Sector & $\begin{array}{l}\text { No of Companies } \\
\text { in CSE }\end{array}$ & $\begin{array}{l}\text { Final } \\
\text { Sample }\end{array}$ & $\begin{array}{l}\text { Representation from } \\
\text { the total population }\end{array}$ \\
\hline Bank finance and Assurance & 60 & 22 & 36.67 \\
\hline Beverage Food and Tobacco & 21 & 14 & 66.67 \\
\hline $\begin{array}{l}\text { Chemicals and } \\
\text { Pharmaceuticals }\end{array}$ & 10 & 5 & 50 \\
\hline $\begin{array}{l}\text { Construction and } \\
\text { Engineering }\end{array}$ & 4 & 2 & 50 \\
\hline Diversified Holdings & 19 & 11 & 57.89 \\
\hline Foot wear and textiles & 3 & 0 & 0 \\
\hline Closed End & 0 & 0 & 0 \\
\hline Health Care & 6 & 5 & 83.33 \\
\hline Hotels and Travels & 37 & 15 & 40.54 \\
\hline Information and Technology & 2 & 0 & 0 \\
\hline Investments & 9 & 5 & 55.56 \\
\hline Land and Property & 19 & 7 & 36.84 \\
\hline Manufacturing & 37 & 16 & 43.24 \\
\hline Motors & 6 & 3 & 50 \\
\hline Oil Palms & 5 & 5 & 100 \\
\hline Plantations & 19 & 5 & 26.32 \\
\hline Power and Energy & 8 & 4 & 50 \\
\hline Services & 8 & 3 & 37.5 \\
\hline Stores Supplies & 4 & 4 & 100 \\
\hline Telecommunication & 2 & 2 & 100 \\
\hline Trading & 8 & 5 & 62.5 \\
\hline & 287 & 133 & 46.34 \\
\hline & & & \\
\hline
\end{tabular}

Source: Constructed by the Authors

The data required for the study was secured via secondary data. The information with regard to governance variables were obtained through the corporate governance information provided in each annual report, which were downloaded from the CSE website. Data for the alternative dependent variables such as ROA and ROE were collected through the financial statements of each annual report. Stock market information was obtained via the CSE website and databases.

The operationalization of the other variables is indicated in Table 5 below 
Table 4: Operationalization of Variables

\begin{tabular}{|c|c|c|c|}
\hline Variable* & Denotation & Measures & Articles used this variables \\
\hline $\begin{array}{l}\text { Return on } \\
\text { Equity }\end{array}$ & ROE & $\begin{array}{l}\text { Net Profit after Tax/Book Value of } \\
\text { Equity }\end{array}$ & $\begin{array}{l}\text { Adjoud,., Zeghal \& Andaleeb, } \\
\text { (2007). } \\
\text { Azeez, (2015) } \\
\text { Manawaduge, (2012). }\end{array}$ \\
\hline Tobin's Q & Tobin's Q & $\begin{array}{l}\text { Market Capitalization+(Book value of } \\
\text { Assets-Book Value of Equity) } \\
\text { Book Value of Equity }\end{array}$ & $\begin{array}{l}\text { Manawaduge, (2012). } \\
\text { Drobetz et.al (2004) }\end{array}$ \\
\hline Leverage & $\mathrm{DE}$ & Total Liabilities/Total Equity & $\begin{array}{l}\text { Azeez, (2015) Manawaduge, } \\
\text { (2012) }\end{array}$ \\
\hline Firm Size & $\operatorname{lnTA}$ & Natural Logarithm of Total assets & \begin{tabular}{|l|} 
Azeez, , (2015) \\
Manawaduge, (2012)
\end{tabular} \\
\hline Firm Risk & Risk & Beta & \\
\hline $\begin{array}{l}\text { Firm } \\
\text { Growth }\end{array}$ & Growth & $\begin{array}{l}\text { Sales Growth } \\
\text { (Salest }- \text { Salest-1)/Salest- } 1 * 100\end{array}$ & Drobetz et.al (2004) \\
\hline
\end{tabular}

Source: Constructed by the authors based on extant literature

\section{Construction of Overall Board Governance Index}

The overall board governance index $(B I)$ that captures the overall monitoring capacity of the board was developed based on key board-compliance requirements that were derived on different corporate governance codesusing ICASL, OECD and UK codes. Accordingly, this board index consists of nine main board related dimensions as follows:

- Chairman

- Nomination Committee

- Audit Committee

- Remuneration Committee

- Re-election

- Company Secretary

- Role of the Board

- Board Meetings

- Board Independence
Each dimension was scored using a Likert scale by measuring 0 to 5 according to the level of compliance. When the companies are not complied the mark has given as 0 . They have complied only with comments is marked as 1 , if company complied in disclosed contents with figures is marked as 5. Principles of Board index are annexed. (Appendix 01)

\section{Conceptual Framework of the study}

Based on the extant empirical and theoretical literature discussed under Section 2 of this study, following conceptual diagram could be drawn, which depicts the relationship between board governance principles and corporate performance. 
This study employs panel

Board of Directors Index

1. Chairman

2. Nomination Committee

3. Audit Committee

4. Remuneration Committee

5. Re-election

6. Company Secretary

7. Role of the Board

8. Board Meetings

9. Board Independence
Corporate Performance

1. $\mathrm{ROE}$

2. Tobin's Q

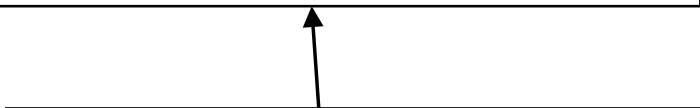

Control Variables

1. Log of Total Assets

2. DEBT/EQUITY Ratio

3. Beta

4. Sales Growth

Figure 1: Conceptual Framework

Source: Constructed by the authors based on extant literature

\section{Data Analyses Strategies}

Several diagnostic tests are performed on the sample data of this thesis. Following previous researches (Alkdai \& Hanefah 2012), the tests for normality, extreme outliers and multicollinearity are carried out. In addition, diagnostic tests particularly for the panel data, including contemporaneous correlation, heteroscedasticity and autocorrelation are also performed on the data.

Regression model to examine the relationship between the Board Index $(B I)$ and their relationship with corporate performance and performed with Housman test for random and fixed effects. This method of analysing the relationship is supported by Madalla et al. (2001). The following regression model is used to test the hypothesis.
ROE / Tobin's $Q=\beta_{0}+\beta_{1} B I+\beta_{2} \ln T A$

$+\beta_{3} D E+\beta_{4}$ Growth $+\beta_{5}$ Risk $+\varepsilon$

\section{RESULTS \& DISCUSSION}

In terms of results, the descriptive analysis of Board index $(B I)$ in the period of 2009 to 2016 revealed that the level of compliance with the principles pertaining to board of directors is only $55 \%$ on an overall basis. Table 6 also illustrates descriptive statistics of board sub-dimensions for the period of 2009 to 2016, and the compliance level of board of directors related to the principles pertaining to audit committees, company secretary and role of the board is at higher levels, but the compliance levels on principles of nomination committee, reelection, board independence is at lower levels, which is observed to be less than $50 \%$. 
Table 5: Descriptive Analysis

\begin{tabular}{lcccrr} 
& Minimum & Mean & Maximum & Skewness & Kurtosis \\
\cline { 2 - 6 } Nomination Committee(NC) & 0 & 23.01 & 92.86 & 0.95 & -0.67 \\
Audit Committee(AC) & 0 & 98.38 & 100 & -7.89 & 65.8 \\
Remuneration Committee(RC) & 0 & 64.69 & 100 & 0.26 & -1.02 \\
Reelection(RE) & 0 & 18.92 & 100 & 1.52 & 0.69 \\
Company Secretary(CS) & 0 & 86.49 & 100 & -0.67 & -0.65 \\
Role of the Board(BR) & 0 & 81.08 & 100 & -1.39 & 0.35 \\
Board Meetings(BM) & 0 & 69.18 & 100 & -0.7 & -0.74 \\
Board Independence(IND) & 0 & 32.39 & 100 & 0.98 & -0.19 \\
\hline Board Index (BI) & 10.58 & 54.92 & 94.07 & 0.3 & 0 \\
\hline
\end{tabular}

In terms of the correlation results, Table 7 shows that the Pearson Correlation (0.045, $p<.0 .10)$ ) has a positive and significant coefficient for the relationship between $B I$ and firm performance as measured by ROE. Thus, this result indicate that financial performance tends to increase with the increase in the level of compliance of board principles as measured by $B I$, as hypothesized under $\mathrm{H}_{5}$. However, unexpectedly, it shows a negative correlation $(-0.131, p<.0 .05)$ with regard to Tobin's Q, which could be attributed to the high market anomalies prevailed in the Sri Lankan context at the period of consideration.

Table 7: Correlation Analysis

\begin{tabular}{|l|l|l|}
\hline Board Index (BI) & ROE & $\begin{array}{l}\text { Tobins } \\
\text { Q }\end{array}$ \\
\hline Correlation Coefficient & 0.071 & -0.131 \\
\hline$p$-value (2-tailed) & 0.17 & 0 \\
\hline
\end{tabular}

Source: Constructed by the Authors

Table 8 shows the panel regression results with the fixed effect model after conducting Hausman test for ROE and Tobin's $Q$ on the independent variables. The results derived from the regression analysis reveals that the Board Index has a significant $(p<.10)$ positive relationship with the firm financial performance as measured by $R O E$.

Table 8: Results of Regression

\begin{tabular}{lllllll}
\hline & \multicolumn{3}{l}{ Model 1-with ROE } & \multicolumn{4}{l}{ Model 2-Tobins_Q } \\
\cline { 2 - 7 } Independent Variables & Coefficient & Std. Error & $\mathrm{P}>\mathrm{t}$ & Coefficient & Std. Error & $\mathrm{P}>\mathrm{t}$ \\
\hline BI & 0.309 & 0.18 & 0.087 & -0.001 & 0.009 & 0.948 \\
Growth & 0 & 0 & 0.141 & 0 & 0 & 0.369 \\
InTA & -7.374 & 3.435 & 0.032 & -0.701 & 0.097 & 0 \\
DE & -0.345 & 3.398 & 0.919 & 0.028 & 0.01 & 0.007 \\
Risk & 0.662 & 1.103 & 0.549 & 0.144 & 0.032 & 0 \\
\hline Constant & 112.417 & 57.053 & 0.049 & 12.578 & 1.877 & 0 \\
\hline
\end{tabular}

Source: Constructed by the Authors 
Table 9 illustrates the results of regression analysis for Return on Equity. The results derived from the regression analysis reveals that the Board Independence has a significant positive relationship with the firm performance measured with ROE. $(\beta=0.037, \rho<0.005)$. Therefore this study supports H1. Next Nomination Committee and Audit Committee exhibit a significant positive relationship with the firm performance measured with ROE. $(\beta=0.700,0.068, \rho<0.005)$ but remuneration committee exhibit no relationship with ROE. Afterwards board meetings and Firm performance exhibit negative relationship with ROE. $(\beta=-0.032, \rho<0.005)$. This will not support.

H3 and supports with Stewardship theory. Company Secretary exhibit negative significant relationship with ROE. ( $\beta=-0.135$, $\rho<0.005)$. Re-election procedure exhibits positive significant relationship with ROE. $(0.030, \rho<0.1)$.but role of board and chairman exhibits no relationship with ROE. According to the results of regression analysis with Tobins_Q the remuneration committee and board meetings have significant negative relationship but no relationship with other variables.

Table 9: Results of Regression with sub-indexes

\begin{tabular}{lllllll}
\hline & \multicolumn{3}{l}{ Model 1-with ROE } & \multicolumn{3}{l}{ Model 2-Tobins_Q } \\
\cline { 2 - 6 } Variable & Coefficient & Std. Error & Prob. & Coefficient & Error & Prob. \\
\hline C & 11.058 & 18.382 & 0.548 & 9.404 & 0.668 & 0.000 \\
Board_Independence & 0.037 & 0.009 & 0.000 & 0.000 & 0.001 & 0.811 \\
Board_Meetings & -0.032 & 0.014 & 0.027 & 0.002 & 0.001 & 0.018 \\
Company_Secretary & -0.135 & 0.047 & 0.004 & -0.002 & 0.002 & 0.197 \\
Chairman & 0.005 & 0.023 & 0.839 & 0.001 & 0.001 & 0.322 \\
Audit_Committee & 0.700 & 0.187 & 0.000 & 0.001 & 0.002 & 0.551 \\
Nomination_Committee & 0.068 & 0.017 & 0.000 & 0.001 & 0.001 & 0.655 \\
Remunration_Committee & -0.210 & 0.129 & 0.104 & -0.011 & 0.005 & 0.032 \\
Relection & 0.030 & 0.010 & 0.004 & 0.001 & 0.000 & 0.043 \\
Role_Of_The_Board & 0.017 & 0.040 & 0.672 & 0.002 & 0.002 & 0.338 \\
Beta & 0.006 & 0.185 & 0.972 & 0.107 & 0.013 & 0.000 \\
Debt_Equity & -0.944 & 0.287 & 0.001 & 0.031 & 0.006 & 0.000 \\
Sales & 0.000 & 0.000 & 0.004 & 0.000 & 0.000 & 0.226 \\
Lntotal_Assets & -2.691 & 0.488 & 0.000 & -0.473 & 0.036 & 0.000 \\
\hline R-squared & 0.815 & & & 0.749 & & \\
Adjusted R-squared & 0.780 & & & 0.702 & & \\
Prob(F-statistic) & 0.000 & & & 0.000 & & \\
Durbin-Watson stat & 1.582 & & & 1.910 & &
\end{tabular}

Source: Constructed by the Authors 


\section{CONCLUSION / FURTHER WORK}

This study has examined the relationship between compliance with board governance principles $(B I)$ and firm performance of listed firms in Sri Lanka. The BI consists of nine main principles including principles on chairmanship, nomination committee, audit committee, remuneration committee, reelection of directors, company secretary, role of the board, board meetings and board independence.

The findings indicated that the average level of BI is only $55 \%$ in the Sri Lankan listed companies and there are considerable variations in level of compliance between the different companies; which shows inadequate board governance compliance levels in Sri Lanka. In terms of the relationship between board governance compliance and level of performance, the correlation and panel regression results suggest that $B I$ is positively associated with firm financial performance but $\mathrm{BI}$ is negatively associated with the market performance. This paper provides mixed evidence on the association between compliance of principles related to board of directors and firm financial performance for a large panel of listed companies in the Sri Lankan context, which is also consistent with prior studies (Adams, Hermalin, \& Weisbach 2010, Renders, Gaeremynck, \& Sercu 2010). This study further suggest compliance with board independence, audit committee and nomination committee impact on positive financial performance whereas board meeting and company secretary impact on negative financial performance.

Accordingly, the study provides empirical evidence for the assertions made by the agency theory. Further, this study is expected to have significant policy implications where policy makers should consider strengthening corporate governance principles related to boards, in order to enhance their financial performance. This study is methodologically significant as the board index has prepared in the Sri Lankan context with an archival data analysis.
In terms of limitations, this study only considered principles related to the board of directors and for the period of 2009 to 2016. Accordingly, future research could expand the scope of corporate governance dimensions as well as expand the period considered.

\section{REFERENCES}

ADAMS, RENEE B., BENJAMIN E. HERMALIN, and MICHAEL S. WEISBACH. 2010. "The Role of Boards of Directors in Corporate Governance: A Conceptual Framework and Survey." Journal of Economic Literature, 48 (1): 58-107.

ADJOUD, F., ZEGHAL, D., \& ANDALEEB, S. 2007. The effect of board's quality on performance: A study of Canadian firms. Corporate Governance 15, 623-635.

AGRAWAL, A., \& KNOEBER, C. R. 1996. Firm performance and mechanisms to control agency problems between managers and shareholders. Journal of Financial and Quantitative Analysis, 31(3), 377-397.

AZEEZ, A.A., 2015. Corporate governance and firm performance: evidence from Sri Lanka. Journal of Finance, 3(1), pp.180-189.

BAYSINGER, B.D. and BUTLER, H.N., 1985. Corporate governance and the board of directors: Performance effects of changes in board composition. Journal of Law, Economics, \& Organization, 1(1), pp.101124.

BHAGAT, S. and BLACK, B., 2001. The non-correlation between board independence and long-term firm performance. J. CorP. l., 27, p.231.

BHAGAT, S., \& BLACK, B. S. 1999. The uncertain relationship between board composition and firm performance. Business Lawyer, 54(3), 921-963. 
BOYD, B. K. 1995 CEO Duality and Firm Performance: A Contingency Model, Strategic Management Journal, 16(4), 301312.

BRICKLEY, J.A., COLES, J.L. AND JARRELL, G., 1997. Leadership structure: Separating the CEO and chairman of the board. Journal of corporate Finance, 3(3), pp.189-220.

CADBURY, A., 1992. The code of best practice. Report of the Committee on the Financial Aspects of Corporate Governance, Gee and Co Ltd, 27.

CARVER, J., 2010. A case for global governance theory: Practitioners avoid it, academics narrow it, the world needs it. Corporate Governance: An International Review, 18(2), pp.149-157.

CHAGANTI, R.S., MAHAJAN, V. and SHARMA, S., 1985. Corporate board size, composition and corporate failures in retailing industry [1]. Journal of management studies, 22(4), pp.400-417.

CHOI, J.J., PARK, S.W. and YOO, S.S., 2007. The value of outside directors: Evidence from corporate governance reform in Korea. Journal of Financial and Quantitative Analysis, 42(4), pp.941-962.

DAILY, C. M. and DALTON, D. R. 1997,CEO and board chair roles held jointly or separately: Much ado about nothing? Academy of Management Executive, 11, 3, 11-20.

DAILY, C.M. and DALTON, D.R., 1992. The relationship between governance structure and corporate performance in entrepreneurial firms. Journal of Business Venturing, 7(5), pp.375-386.

DIONNE, G. and TRIKI, T., 2005. Risk management and corporate governance: The importance of independence and financial knowledge for the board and the audit committee. Cahier de recherche/Working Paper, 5, p.15.

HAREENDRA DISSABANDARA, 2010 Corporate Governance Best Practices and Current Views based on Evidence from Sri Lankan Corporate Boards . Listed Company Directors' Conference of the Securities \& Exchange Commission of Sri Lanka.

DONALDSON, L. and DAVIS, J.H. 1994, "Boards and company performance research challenges the conventional wisdom", Corporate Governance, Vol. 2 No. 3, pp. 151-160.

DULEWICZ, V. and HERBERT, P., 2004. Does the composition and practice of boards of directors bear any relationship to the performance of their companies?. Corporate Governance: An International Review, 12(3), pp.263-280.

DROBETZ, W., SCHILLHOFER, A. and ZIMMERMANN, H., 2004. Corporate governance and expected stock returns: Evidence from Germany. European financial management, 10(2), pp.267-293.

EZZAMEL, M. and WATSON, R., 1993. Organizational Form, Ownership Structure and Corporate Performance: A Contextual Empirical Analysis of UK Companies 1. British Journal of Management, 4(3), pp.161-17.

FAMA, EF and JENSEN, MC 1983, 'Agency problems and residual claims', Journal of law and economics, vol. 26, no. 2, pp. 327-349.

FRANCIS, B.B., HASAN, I. and WU, Q., 2012. Do corporate boards matter during the current financial crisis?. Review of Financial 
Economics, 21(2), pp.39-52.

GRACE, M., IRELAND, A. and DUNSTAN, K., 1995. Board composition, non-executive directors' characteristics and corporate financial performance. AsiaPacific Journal of Accounting, 2(1), pp.121137.

HILLMAN, A. J., NICHOLSON, G. J., \& SHROPSHIRE, C. 2008. Directors' multiple role identities, identification and board monitoring and resource provision. Organization Science, 19: 441-456.

HOSSAIN, M.A., PREVOST, \& ROA, R.2001. Corporate Governance in New Zealand: The effect of the 1993 Companies Act on the relation between board composition and firm performance. Pacific Basin Finance Journal, 9, pp.119-145.

HUSSEY, J. and HUSSEY, R., 1997. Business research.\& Klein, A., 1998. Firm performance and board committee structure. The Journal of Law and Economics, 41(1), pp.275-304.

MADDALA, G. S.,HONGY Li \&,V,K Srivastava . (2001), 'A Comparative Study of Different Shrinkage Estimators for Panel Data Models', ANNALS OF ECONOMICS AND FINANCE, 2, pp. 1-30. Available at: http://aeconf.com/Articles/May2001/aef0201 01.pdf (Accessed: 5 April 2015).

MAK, Y.T. and KUSNADI, Y., 2005. Size really matters: Further evidence on the negative relationship between board size and firm value. Pacific-Basin Finance Journal, 13(3), pp.301-318.

MANAWADUGE, A.S., 2012. Corporate governance practices and their impacts on corporate performance in an emerging market: the case of Sri Lanka.

MONKS,ROBERT AG and NELL MINOW
1996 watchng the watchers: Corporate Governance for the 21st Century, Blackwell Publishing.

NTIM, C.G. and OSEI, K.A., 2011. The impact of corporate board meetings on corporate performance in South Africa. African Review of Economics and Finance, 2(2), pp.83-103.

OECD 1999 OECD Principles of Corporate Governance. Paris: OECD.

PEARCE, J.A. and ZAHRA, S.A., 1991. The relative power of CEOs and boards of directors: Associations with corporate performance. Strategic management journal, 12(2), pp.135-153.

RASHID, A., De ZOYSA, A., LODH, S. and RUDKIN, K., 2010. Board composition and firm performance: Evidence from Bangladesh. Australasian Accounting, Business and Finance Journal, 4(1), pp.7695.

RECHNER, P.L. and DALTON, D.R., 1986. Board composition and shareholder wealth: An empirical assessment. International Journal of Management, 3(2), pp.86-92.

RENDERS, A., GAEREMYNCK, A., \& SERCU, P. 2010. Corporate-governance ratings and company performance: A crossEuropean study. Corporate Governance: An International Review, 18(2), 87-106.

SANDA, A.U, A.S, MIKAILU and T, GARBA, 2005: "Corporate governance mechanisms and firm financial performance in Nigeria", AERC Research Paper 149, Nairobi.

TRICKER,B.2015 Corporate Governance; Principles,Policies and Practices, Oxford University Press Inc,UK

VAFEAS,N.,\&THEODOROU, E. 1998. The 
association between board structure and firm performance in theUK. British Accounting Review, 30(4), 383-407.

VAN ESSEN, M., VAN OOSTERHOUT, J.H. and Carney, M., 2012. Corporate boards and the performance of Asian firms: A metaanalysis. Asia Pacific Journal of Management, 29(4), pp.873-905.

WEIR, C., LAING,D., \& MCKNIGHT, P. J. 2002. Internal and external governancemechanisms: Their impact on the performance of large UK companies. Journal of Business Finance \& Accounting, 29(5-6), 579-611.

YERMACK, D., (1996). Higher market valuation of companies with a small board of directors. Journal of financial economics, 40(2), pp.185-211.

\section{APPENDIX}

\section{Appendix 01-Principles of Board Index Chairman}

1. The annual report should identify the chairman, the deputy chairman (where there is one), the chief executive, the senior independent director and the chairmen and members of the board committees.

2. The chairman should hold meetings with the non-executive directors without the executives present.

3. For the appointment of a chairman, the nomination committee should prepare a job specification, including an assessment of the time commitment expected, recognising the need for availability in the event of crises.

4. A chairman's other significant commitments should be disclosed to the board before appointment and included in the annual report.

5. changes to such commitments should be reported to the board as they arise, and their impact explained in the next annual report.

6. The chairman should ensure that new directors receive a full, formal and tailored induction on joining the board directors should avail themselves of opportunities to meet major shareholders.

7. The chairman should regularly review and agree with each director their training and development needs.

\section{Nomination Committee}

1. Boards should consider assigning a sufficient number of non-executive board members capable of exercising independent judgement to tasks where there is a potential for conflict of interest.

2. There should be a nomination committee which should lead the process for board appointments and make recommendations to the board.

3. A majority of members of the nomination committee should be independent non-executive directors.

4. The chairman or an independent nonexecutive director should chair the committee, but the chairman should not chair the nomination committee when it is dealing with the appointment of a successor to the chairmanship.

5. The nomination committee should make available its terms of reference, explaining its role and the authority delegated to it by the board.

6. The nomination committee should evaluate the balance of skills, experience, independence and knowledge on the board and, in the light of this evaluation, prepare a description of the role and capabilities required for a particular appointment.

7. Non-executive directors should be appointed for specified terms subject to re-election and to statutory provisions 
relating to the removal of a director.

8. Any term beyond six years for a nonexecutive director should be subject to particularly rigorous review, and should take into account the need for progressive refreshing of the board.

9. A separate section of the annual report should describe the work of the nomination committee, including the process it has used in relation to board appointments.

10. This section should include a description of the board's policy on diversity, including gender, any measurable objectives that it has set for implementing the policy, and progress on achieving the objectives.

11. The terms and conditions of appointment of non-executive directors should be made available for inspection

12. The letter of appointment should set out the expected time commitment.

13. Non-executive directors should undertake that they will have sufficient time to meet what is expected of them.

14. Their other significant commitments should be disclosed to the board before appointment, with a broad indication of the time involved and the board should be informed of subsequent changes.

\section{Audit Committee}

1. The board should satisfy itself that at least one member of the audit committee has recent and relevant financial experience

2. The main role and responsibilities of the audit committee should be set out in written terms of reference

3. The terms of reference of the audit committee, including its role and the authority delegated to it by the board, should be made available

4. Where requested by the board, the audit committee should provide advice on whether the annual report and accounts, taken as a whole, is fair, balanced and understandable and provides the information necessary for shareholders to assess the company's position and performance, business model and strategy

5. The audit committee should review arrangements by which staff of the company may, in confidence, raise concerns about possible improprieties in matters of financial reporting or other matters.

6. The audit committee's objective should be to ensure that arrangements are in place for the proportionate and independent investigation of such matters and for appropriate follow-up act

7. The audit committee should monitor and review the effectiveness of the internal audit activities.

8. Where there is no internal audit function, the audit committee should consider annually whether there is a need for an internal audit function and make a recommendation to the board, and the reasons for the absence of such a function should be explained in the relevant section of the annual report

9. The audit committee should have primary responsibility for making a recommendation on the appointment, reappointment and removal of the external auditors.

10. If the board does not accept the audit committee's recommendation, it should include in the annual report, and in any papers recommending appointment or reappointment, a statement from the audit committee explaining the recommendation and should set out reasons why the board has taken a different position.

11. A separate section of the annual report should describe the work of the committee in discharging its responsibilities.

12. The significant issues that the committee considered in relation to the financial statements, and how these issues were addressed; 
13. An explanation of how it has assessed the effectiveness of the external audit process and the approach taken to the appointment or reappointment of the external auditor, and information on the length of tenure of the current audit firm and when a tender was last conducted

14. If the external auditor provides non-audit services, an explanation of how auditor objectivity and independence are safeguarded.

\section{Remuneration Committee}

1. In designing schemes of performancerelated remuneration for executive directors, the remuneration committee should follow the provisions in Schedule A to this Code.

2. Schemes should include provisions that would enable the company to recover sums paid or withhold the payment of any sum, and specify the circumstances in which it would be appropriate

3. Where a company releases an executive director to serve as a non-executive director elsewhere, the remuneration report should include a statement as to whether or not the director will retain such earnings and, if so, what the remuneration is.

4. Levels of remuneration for non-executive directors should reflect the time commitment and responsibilities of the role. Remuneration for non-executive directors should not include share options or other performance-related elements.

5. If, exceptionally, options are granted, shareholder approval should be sought in advance and any shares acquired by exercise of the options should be held until at least one year after the nonexecutive director leaves the board.

6. The remuneration committee should carefully consider what compensation commitments (including pension contributions and all other elements) their directors 'terms of appointment would entail in the event of early termination. The aim should be to avoid rewarding poor performance.

7. they should take a robust line on reducing compensation to reflect departing directors' obligations to mitigate loss.

8. Notice or contract periods should be set at one year or less.

9. The board should establish a remuneration committee of at least three, or in the case of smaller companies two, independent non-executive directors.

10. In addition the company chairman may also be a member of, but not chair, the committee if he or she was considered independent on appointment as chairman.

11. The remuneration committee should make available its terms of reference, explaining its role and the authority delegated to it by the board.

12. Where remuneration consultants are appointed, they should be identified in the annual report and a statement made as to whether they have any other connection with the company.

13. The remuneration committee should have delegated responsibility for setting remuneration for all executive directors and the chairman, including pension rights and any compensation payments.

14. The committee should also recommend and monitor the level and structure of remuneration for senior management.

15. The board itself or, where required by the Articles of Association, the shareholders should determine the remuneration of the non-executive directors within the limits set in the Articles of Association.

16. Where permitted by the Articles, the board may however delegate this responsibility to a committee, which might include the chief executive.

17. Shareholders should be invited 
specifically to approve all new long-term incentive schemes (as defined in the Listing Rules23) and significant changes to existing schemes, save in the circumstances permitted by the Listing Rules.

\section{Re-election}

1. All other directors should be subject to election by shareholders at the first annual general meeting after their appointment, and to re-election thereafter at intervals of no more than three years.

2. Non-executive directors who have served longer than nine years should be subject to annual re-election.

3. The names of directors submitted for election or re-election should be accompanied by sufficient biographical details and any other relevant information to enable shareholders to take an informed decision on their election.

4. The board should set out to shareholders in the papers accompanying a resolution to elect a non-executive director why they believe an individual should be elected.

5. chairman should confirm to shareholders when proposing re-election that, following formal performance evaluation, the individual's performance continues to be effective and to demonstrate commitment to the role.

\section{Board evaluation - self and group}

1. The board should state in the annual report how performance evaluation of the board, its committees and its individual directors has been conducted.

2. The non-executive directors, led by the senior independent director, should be responsible for performance evaluation of the chairman, taking into account the views of executive directors

\section{Company Secretary}

1. The board should ensure that directors, especially non-executive directors, have access to independent professional advice at the company's expense where they judge it necessary to discharge their responsibilities as directors.

2. All directors should have access to the advice and services of the company secretary, who is responsible to the board for ensuring that board procedures are complied with.

3. Both the appointment and removal of the company secretary should be a matter for the board as a whole.

\section{Role of the Board}

1. Board members should act on a fully informed basis, in good faith, with due diligence and care, and in the best interest of the company and the shareholders.

2. The annual report should include a statement of how the board operates, including a high level statement of which types of decisions are to be taken by the board and which are to be delegated to management.

\section{Board Meetings}

1. It should also set out the number of meetings of the board and those committees and individual attendance by directors.

2. The board should meet sufficiently regularly to discharge its duties effectively.

3. There should be a formal schedule of matters specifically reserved for its decision.

\section{Board Independence}

1. The board should appoint one of the independent non-executive directors to be the senior independent director to provide a sounding board for the chairman and to 
serve as an intermediary for the other directors when necessary.

2. The senior independent director should be available to shareholders if they have concerns which contact through the normal channels of chairman, chief executive or other directors has failed to resolve or for which such contact is inappropriate.

3. Led by the senior independent director, the non-executive directors should meet without the chairman present at least annually to appraise the chairman's performance and on such other occasions as are deemed appropriate.

4. Where directors have concerns which cannot be resolved about the running of the company or a proposed action, they should ensure that their concerns are recorded in the board minutes.

5. On resignation, a non-executive director should provide a written statement to the chairman, for circulation to the board, if they have any such concerns

6. The board should identify in the annual report each non-executive director it considers to be independent.

7. The board should determine whether the director is independent in character and judgement and whether there are relationships or circumstances which are likely to affect, or could appear to affect, the director's judgement.

8. The board should state its reasons if it determines that a director is independent notwithstanding the existence of relationships or circumstances which may appear relevant to its determination, including if the director

9. The board should be able to exercise objective independent judgement on corporate affairs.

10. Boards should consider assigning a sufficient number of non-executive board members capable of exercising independent judgement to tasks where there is a potential for conflict of interest. 